\title{
INTRODUCTION: THE POLITICAL ECONOMY OF MANAGERIALISM
}

\author{
Matthew Eagleton-Pierce and Samuel Knafo \\ Review of International Political Economy \\ Volume 27, 2020 - Issue 4 \\ Special Issue on the Political Economy of Managerialism
}

Post-Peer Review Revised Copy

FINAL COPY

\begin{abstract}
As a set of ideas and practices, managerialism has arguably become a powerful behavioural logic shaping a range of processes and outcomes of governance in the world economy. Yet IPE has yet to directly interrogate managerialism as a distinct object of analysis. In this special issue, we bring together a range of authors to explore how managerialism reveals a set of complex histories, agents, and implications that are not selfevident and carry direct relevance for how we understand the global economy. Our main contention is that managerialism is not simply a technical means for the pursuit of policies, but has come to shape the very ways in which policy, and governance more generally, are conceived and conducted. Across a range of cases and fields, we dissect the emergence of the managerial logic, along with how it produces uneven mutations, ruptures, and forms of resistance. In doing so, we reflect upon the requirements for developing a political economy of managerialism.
\end{abstract}

\section{Keywords}

Managerialism, Governance, History of ideas, Power, Ideology 
Strategic Planning. Results-Based Frameworks. Key Performance Indicators. Reputational Risk. Public-Private Partnerships. The vocabulary of management speak has become familiar to many of us over recent decades. Twenty years ago, the OECD argued that 'a major cultural shift' was underway, defined by 'a new paradigm which attempts to combine modern management practices with the logic of economics, while still retaining the core public service values' (OECD 1998: 5). Normalised in certain areas, strongly contested in others, managerialism has become increasingly common within the organisation of global governance. A cluster of expressions, some popular, others more academic, have tried to encapsulate this transformation, such as 'administrative reform' (Aucoin 1990), 'national competitiveness' (Porter 1990), 'new public management' (Hood 1991, 2007; Lynn 2006), and 'entrepreneurial government' (Osborne and Gaebler 1992; Mazzucato 2013). They reflect the ways in which the rise of 'public management' has challenged the traditional separation established between private and public governance. Among common justifications, the managerial vision is claimed to enhance efficiency, expand markets, and provide employment opportunities. Today, one can observe how managerialism continues to transform entities that have a stake in the world economy, including states, firms, international institutions, and non-governmental bodies (Locke and Spencer 2013; Dardot and Laval 2014; Davies 2014; Hanlon 2015). In other words, managerialism has arguably become a powerful behavioural logic shaping a range of processes and outcomes of governance.

If such debates are visible within a variety of issue areas and complexes, it remains surprising that International Political Economy (IPE) has not directly interrogated managerialism as a distinct object of analysis. Where IPE authors have discussed themes associated with the political economy of managerialism, such engagements have tended to be limited or oblique, without any major theoretical or empirical investigation. Three reasons could be offered for this distancing or neglect. First, the study of management theory and practice has historically been housed within other disciplinary fields, notably management studies, public administration, and organisation studies. Within this scholarly division of labour, IPE has been seemingly content, consciously or otherwise, to cede academic territory to these adjacent areas. Second, one could suggest that some IPE researchers may read management as something largely preoccupied with the 'internal' and 'mechanical' features of organisations, particularly corporate enterprises. It has not helped that management is criticised at times as a 'lightweight' intellectual endeavour. Management studies, and the popular business management literature in particular, have often been dismissed for reproducing an uncritical discourse on capitalism which, in turn, has arguably suppressed levels of IPE interest. Third, even where managerialism has been noted in IPE literature, the subject has often been subsumed under what is seen as broader concerns with neoliberalism, neoclassical economics or, more abstractly, as an expression of contemporary bureaucratisation (Graeber 2015). Managerialism can thus appear as a subordinate theme concerned with the narrower question of how specific agendas are implemented or put into practice. In all these ways, therefore, the topic has rarely been tackled head on in IPE and tends to pass underexamined.

We argue here, by contrast, that the political economy of managerialism deserves its own analytical spotlight and is worthy of serious attention by IPE researchers. Within this special issue, we bring together a range of authors, in and around IPE, to explore how managerialism reveals a range of complex histories, agents, and implications that are not self-evident and carry direct relevance for how we understand the world economy. From tracing the wider 
history and rising status of managerial ideas and the promotion of key frameworks, such as risk and performance management; to exploring how management consultants shape the choices and organisational design of governmental and non-state actors, the articles in this special issue showcase the manifold ways in which managerialism carries concrete impacts. Our main contention is that managerialism is not simply a technical means for the pursuit of policies, but has come to shape the very ways in which policy, and governance more generally, are conceived and conducted. Managerialism, we suggest, can be viewed as a connecting tissue within the body of the global political economy, one which features particular ideational and institutional forms. These forms carry a discernible aura, thus enabling empirical identification, but at the same time are enmeshed or clash within institutions that have been made by many traditions beyond managerialism. Our aim is therefore to plot and explain how the international political economy of managerialism has historically revealed itself, along with corresponding attention to how it continues to produce uneven mutations, ruptures, and forms of resistance.

To provide the context for this special issue, the following introduction consists of four sections. First, we outline the analytical treatment of managerialism in IPE, pointing to the limited contributions and insights seen so far in the existing literature. Second, given that managerialism is often an unclear and slippery term, with meanings that can be appropriated in a variety of ways, we critically unpack and question some core modalities of the concept. This initial conceptual mapping will also serve to inform and organise a number of the subsequent articles. Third, given the importance we devote to historicising managerialism as an object, we also offer a sketch of major phases of management thought and practice. This discussion will, in turn, seek to destabilise a tendency to view managerialism as a transhistorical category. With this framework in mind, we turn in the fourth section to outline the papers that constitute the issue, as well as offering concluding guidance on how the study of managerialism can continue to advance and enrich the study of IPE and neighbouring fields.

\section{The Study of Managerialism in IPE}

Within early IPE scholarship, particularly where transnational corporations were debated, one can find some references to the organisation of management and its political economy implications. Although not explicitly interested in managerialism, Stephen Hymer (1970) discussed the hierarchy of decision-making within large firms, from Marshallian roots to the multidivisional and multinational firm of the modern period. From a different perspective, Raymond Vernon explored the notion of business strategy in Storm Over the Multinationals (1977). Building on his earlier Sovereignty at Bay (1971), the book examined the wider ties between states and firms, notably through the product life cycle model but also in reference to leadership issues and national corporate cultures. In both cases, management was considered mostly as a means to account for why firms developed transnational networks.

During the 1980s and 1990s, Susan Strange was at times preoccupied with the category of managers in the world economy and what she argued was an 'emerging managerial technocracy' (Stopford and Strange 1991: 22). Her work shed light on the new authority of the corporation and their management in the global economy. She pointed to the importance of large management consultancy houses, the increasing role of risk management across 
different institutions (Strange 1988, 1996), and remarked on how corporate managers negotiate cultural complexity across borders (Stopford and Strange 1991: 196-199).

These themes have been explored further by a critical IPE literature, specifically the Marxist and neo-Gramscian traditions, where the theme of managerialism has surfaced under different guises. Most significantly, Robert Cox (1987: 358-360) helped to open up research focused on the so-called 'transnational managerial class', a group which he argued includes not only corporate elites, but officials in national and international agencies tasked with economic policy, along with a wide range of other experts and specialists (including management consultants and business educators) (also see Cox 1993; Gill 1995). ${ }^{1}$ In turn, Kees van der Pijl (1998) helped to extend such thinking, both historically and sociologically, suggesting that managerial cadres were constituting themselves as an authoritative group across private and public institutions. Such players tend to view themselves as thoroughly modern subjects, with a fascination towards 'steering' change and directing the future, along with a corresponding orientation to whatever is the dominant rationality of the period (van der Pijl 2005, 2012). Similar to Strange, and with a gesture towards themes examined by authors in this special issue (Seabrooke and Sending, Whiteside), van der Pijl anticipated how key agents of managerialism were growing in authority: 'consultancies and their equivalents are in effect laying the groundwork for a system of global governance' (van der Pijl 1998: 162).

These authors gave hints at how managerialism could be considered as an object of interest for IPE, but discussions of this managerial disposition in IPE remained limited. Despite alluding to the growing influence of managers and agents of managerialism, little was done to reflect on and historicise managerial practices and their impact on governance at various levels of the global economy. In the past twenty years, this situation has partially improved when considering two groups of literature. A first set of authors draw on the lineage of earlier IPE debates to explore how private authority configures and constitutes itself in the world economy. There is now greater recognition of corporate managers, and their consultants, in matters of governance. For instance, Louise Amoore $(2002,2006)$ argues that consultancy, accounting and auditing firms, such as McKinsey \& Company, are inherently political actors who, in the process of selling their 'technical' managerial expertise, became almost extensions of states and international organisations. As she suggests, IPE should thus be concerned with how the firm itself is being made and remade through pervasive management discourses and, in turn, how these represent the global political economy to us in particular ways' (Amoore 2006: 63). Such insights can be coupled with wider IPE accounts on business power in global governance (Hall and Biersteker 2002; May 2006, 2015; Fuchs 2007; Ougaard and Leander 2010; Momani 2013), as well as the field of 'global private politics' which explores how firms acquire regulatory capacity and shape international standards across different policy domains (Perry and Nölke 2006; Büthe 2010; Büthe and Mattli 2011).

A second set encompasses a range of authors who have addressed topics linked to the political economy of management, even if such arguments have not been explicitly anchored by the concept or history of managerialism. Here, one can highlight research on particular

\footnotetext{
${ }^{1}$ The more widely used concept of 'transnational capitalist class' can be treated as synonymous with 'transnational managerial class', but some authors, such as Sklair (2001) and Budd (2013), have preferred to retain a distinction, reflecting debates between neo-Gramscianism and Marxism.
} 
notions, themes, and patterns which we suggest carry a managerial imprint, including: Fouger's $(2006,2008)$ analysis of the norm of competitiveness in the context of Michael Porter's work with the World Economic Forum; the evaluation of risk management, particularly in light of financialisation trends (Dannreuther and Lekhi 2000; Lockwood 2015; Baines 2017); writing on 'global benchmarking' and the political economy of numbers (Broome and Quirk 2015); the wider culture of professional networks (Seabrooke and Henriksen 2017); as well as references to the rise of New Public Management, particularly within the study of neoliberalism (Harrison 2005; Peters 2012; Best 2014; Davies 2014). We would suggest that across these diverse research enquiries, managerialism can be proposed as a crosscutting problem which carries important ideational and institutional implications for the global political economy. However, even within these debates, managerialism is too often approached tangentially as a subordinate theme used to illustrate broader issues. IPE scholars tend to read managerial phenomena as extensions of more traditional concerns, with the result that managerialism is rarely taken as an object of study in its own right. ${ }^{2}$

The paucity of in-depth thinking on managerialism has thus entrenched a disciplinary divide which has seen IPE researchers focus on broader patterns of governance while leaving other fields to address questions related to concrete managerial practices. When engaging topics that concern managerialism, IPE scholars often privilege other systems of knowledge in order to gain perspective on what they study, notably neoliberal theory or neoclassical economics. The result is a proclivity to take-for-granted managerial techniques as being somehow straightforward extensions of neoliberal forms of governance. In this process, management is too often treated as being primarily concerned with the mundane implementation of policies, operating at a lower level of organisational activity. By contrast, we argue that one can only grasp what is involved politically in these transformation by taking managerialism on its own terms. For this notion does not simply constitute a loose pejorative term. It points to a more complex socio-politico phenomenon.

\section{Why Managerialism?}

This special issue takes managerialism, rather than management, as it main focus. Such an orientation stems from our interest in the politics of these practices and the ways they are actively promoted in various areas of social life. Management, as a term, has a more general connotation tied to modern administration. It covers a broad set of practices and can be variously understood as a particular class of individuals who administer organisations; as a body of knowledge, skills, and competencies; or as a wider set of behaviours. By contrast, the expression managerialism is sometimes invoked to signal the rise of a managerial class and the mainstreaming of a related ideology (Locke and Spender 2012; Cunliffe 2014; see for instance, Drucker 1973). Managerialism thus refers to programmatic movements characterised by the self-awareness of their proponents and what is often a proselytising disposition. This involves certain ways of representing the social world which are often legitimated by casting concerns in universal terms. When effective, such representations are translated into material interventions in particular institutions, potentially reshaping behavioural patterns and norms (Grey 2017). In a basic sense, therefore, the concept of

\footnotetext{
2 For additional, notable exceptions see Schwartz 1994; and Thrift 2002.
} 
managerialism points to the processes through which management ideas and practices spread across space and time.

Among the biggest obstacles to the study of managerialism, which in turn this special issue aims to address, is a tendency to reify and normalise it as a form of power that one would expect from dominant actors in the global economy. The rhetoric that fuels managerialism can often reinforce this impression by promoting its practices as the product of common sense. Managerialism often appeals to basic universal concerns in order to legitimise its politics in seemingly irrefutable terms. Its core discourse lives off a deceptively simple premise: problems can be improved or even resolved if they are better managed. In this respect, manageability has been built as a normatively desirable form of social action (Grey 1996, 2017). Reduced to an elementary sense, managerialism presents itself as a belief that the world should and can be managed, involving ideologies informed by instrumental rationality, and techniques directed towards the control of organisations and other social outcomes. From this perspective, it is difficult not to see management as a somewhat transhistorical practice, a product of modernism and its aspiration for a rational ordering of the world. This apparent rational grounding of management explains why critiques themselves have often seen this desire as emanating from the structural conditions of an expanding capitalist system or the rise of the bureaucratic state, even when it is recognised that the 'orientation to manage' (Kallinikos 1996: 37 ) is a more complex historical phenomenon.

This normalising perspective has therefore reinforced three basic propositions about managerialism that can at times appear unassailable. The first is that managerialism is grounded in a major call for ordering that appeals to a human desire for ontological security and continuity (Giddens 1991). Managerial knowledge claims to promote the reduction of ambivalence, ambiguity, and uncertainty, often through treating such conditions as inherently threatening (Bauman 1991). In this respect, managerialism appears to tap into a latent anxiety by offering the promise that a confusing world should be tamed and, in turn, that mastery can be achieved by deploying management ideas and practices. To proponents, managerialism becomes 'an optimistic, almost romantic creed' (Pollitt 1993: 1). Embedded within the epistemic foundations of modernity, this core assumption of manageability often has a taken-for-granted quality. It builds on a certain modern conception of agency; that is, an autonomous self, detached from the environment, yet able to act on the external world (Kallinikos 1996; Townley 2002; also see Roberts 1984; Maclntyre 2014[1981]; Luke 1990).

The second proposition is that managerialism essentially consists of the deployment of rational instrumentalism as a means to address this need for ordering. As many scholars have argued, managerialism encompasses theories, models, and frameworks which carry a Weberian imprint of formal or instrumental rationality (Edwards 1980; Watson 1994). This instrumental rationality emphasises calculation, deliberateness, and predictability in order to formulate the most efficient relationship between means and ends (Weber 2013[1922]). Whether this efficiency is actually accomplished is an empirical question, but the ideological consistency of seeking efficiency is a hallmark of managerialism. It often exploits a critique of the state, to present itself as a means to get more with less, a practice which fits both with the desire to delimit the state under neoliberalism and use market mechanisms to enforce greater performance. Such appeals to rationality are often embedded within institutional 
policies that include attention to the application of rules, laws, and regulations which are, by way of justificaition, often represented as fair or technical.

The third proposition is that managerialism fundamentally boils down to a problematique of control (Clegg 1981; Beniger 1989; Chau, Lowe, and Puxty 1989; Reed 1989; Otley, Broadbent, and Berry 1995; Berry et al. 2009). The entire history of management thought since the nineteenth century can thus be summarised as a process of wrestling with methods of control operating at systemic, organisational, and individual levels. In mainstream perspectives, the theme of control pivots around how to ensure a degree of internal equilibrium in relation to demands and threats from the surrounding environment. Control is subsequently imagined and practiced through various interrelated mechanisms and techniques. Such processes are often concerned with functional specialisation, compartmentalisation, and the monitoring of tasks. In critical perspectives, particularly those shaped by Marxism, the problem of managerial control is defined as an effort to stabilise and mystify dehumanising class relations between privileged cadres (managers) and an exploited group (workers).

The saliency of these three themes may be partly due to the fact that managerialism has been contested at multiple levels. For the attempt to cast managerialism in terms of order, instrumental rationality and control arguably reflects the challenges faced by its proponents when seeking to legitimate their practices. There have been substantial debates over the extent to which these managers succeed in their declared or implicit aspiration for control (Ferguson 1994). Protests, miscalculations, accidents, and mundane ignorance inevitably blur the deceptively straight lines of managerial reason. Indeed, questioning the presumed effectiveness of managerial practices, and thus further opening up the category itself, is a theme which is critically probed by a number of authors in this special issue, such as Moore and Joyce, Nunn, and Eagleton-Pierce. We would therefore concur with others who have argued that managerialism contains tensions and contradictions within itself and is often 'perennially failing' to accomplish its objectified ends (Grey 2017: 27). Despite frequent promises and high expectations at the outset of initiatives, managerial practices often stumble through cycles of crisis, innovation, and reform (Power 2004). Such patterns may be acknowledged by relevant parties and audiences, and can be accompanied by scepticism and cynicism, but the need to be seen to be in control, at the very least, serves as a powerful underlying motivation for reproducing managerialism and its key discursive modalities. As Maclntyre (2014[1981]: 124) suggests, managerial expertise often creates an 'illusion' of social control. Such problems of legitimation have, in turn, fuelled the self-reflexive nature of management in its attempts to lay claims to a given expertise or professionalize its practices.

These analyses point to the fact that one should be careful to not take-for-granted how proponents of managerial practice present their activities, even if we are critical of such pursuits. The themes of ordering, instrumental rationality, and control may constitute important baselines to understand managerialism, but we should be cautious about crafting the ideological properties of managerialism into an overly neat package that, in practice, encompasses a wide range of concrete experiences and consequences. Thus, our problem here is not so much if rationalism or the desire for control are at stake or not - something that would be difficult to deny - but rather the problematic framing that results from underspecified accounts of managerial processes in IPE. In particular, by appealing to the same universal register as the one deployed by the apostles of managerialism, scholars can 
risk levelling the field in ways which make it hard to historicise or relativise managerialism as a distinct social practice. To this end, we must guard against treating all forms of management as expressions of a single phenomenon and often cast as various iterations of scientific managerialism or, more specifically, Taylorism.

With this in mind, one of the cross-cutting, intellectual concerns explored by the contributors to this special issue is how managerialism can often direct our gaze towards efficiency-based concerns yet, at the same time, we see managerial practices that have increasingly come to define larger priorities and agendas of governance. As the articles explore, managerialism cannot be seen simply as a narrow strategy directed towards mechanical efficiency for the purpose of concrete transformation, such as involving the labour process. Rather, its tentacles have become intertwined with the design of policy, helping to determine objectives of governance or even shaping the very process of decision-making. Thus, as the phenomenon of managerialism has spread to a variety of institutional spaces and fields, becoming part of how organisations think and act, we are arguably seeing new mutations of managerial reason when compared to earlier histories. We therefore see managerialism as something much more encompassing and embracing than the internal refinement of organisations under the direction of a privileged set of cadres.

In this respect, our concerns with managerialism speak directly to the remaking of global governance in ways that are often underestimated in the literature, precisely because managerialism is too often cast as a presumed apolitical 'tool of efficiency' to pursue a given objective. Exploring the deeper political economy implications of these practices in shaping the agenda of various forms of governance at a global level, the authors in this special issue dissect how managerialism has become vital in reconfiguring economic policy norms (Linsi) and development policy programmes (Seabrooke and Sending, Sharma and Soederberg, Eagleton-Pierce); the restructuring of welfare states and the wider public sector (Knafo, Nunn, Whiteside); the shaping of corporate power and governance arrangements (Baglioni, Campling and Hanlon; Moore and Joyce; Sharma and Soederberg), as well as penetrating into NGOs that have historically been resistant to such logics (Eagleton-Pierce). By directly connecting our analysis with enduring IPE research themes, we therefore argue that explaining managerialism does not simply stand on its own but is now interwoven with understanding the politics of the world economy.

\section{Developing a Historical Perspective on Managerialism}

Conceptualisations of managerialism are often derived from how scholars understand the relationship between the particular practices that are claimed to fall under its name and the wider social context. Depending upon the way in which we conceive of the lineages of current managerial practices and their distinctive development since the 1980s or 1990s, our understanding of its nature and significance can change in profound ways. In this respect, therefore, a key axis that shapes many of the contributions in this special issue is the way in which we conceive of the relationship between managerialism and broader concepts vital for political economy analysis, such as capitalism or neoliberalism. For some, managerialism constitutes an integral aspect of the development of capitalism, understood as a set of practices intended to reinforce the logic of commodification and the creation of new 
opportunities for profit, or as part of some wider disciplining process. From this perspective, one cannot understand managerialism without a broader conception of modern capitalism and its evolution and, in turn, what makes current managerial practices interesting is their intimate relationship to specific phases of capitalist development.

The advent of scientific management in the late $19^{\text {th }}$ century (Hoskin and Macve 1994) is often a key historical reference point when charting approaches that examine the relationship of managerialism to capitalism. Scientific managerialism was most famously associated with Frederick Winslow Taylor, who became known for his studies aimed at optimising work stations and minimising non-productive time through planning and careful organisation. Scientific management was tied to the rapid growth of the American corporation which saw the rise of middle managers who often came with applied expertise, notably in engineering and accounting (Chandler 1977). These managers were employed to help with logistical and workplace organisation. They sought to legitimise their work with the establishment of business schools which accredited management as a distinct professional body of expertise (Khurana 2007). Taylorism was the origin of a first connotation often associated to managerialism: the emphasis on control through standardisation and careful benchmarking in order to monitor and ensure efficiency gains. Scientific managerialism became more generally understood as the use of science for organising the workplace more efficiently, a movement which was also tied to the rise of human resources. In turn, such thinking became associated with principles taught to new cadres, and generalised (aspiring to be a 'science') for how to discipline labour and deal with welfare and democratic forces from an elite perspective. It fuelled a critical literature that focused on the power relations that managers enforce and the dynamics of domination and alienation they engender (Braverman 1974).

A focus on the legacy of scientific managerialism is important, as various contributors to this special issue argue, not only because it helps to bring out the disciplinary nature of managerialism but also because it helps us better specify what are the novel features behind the current redeployment and reconfiguring of such managerial practices on a global scale. Here, it is argued there is much to learn by examining the specific features of accumulation under neoliberalism to grasp the new purpose of these managerial practices.

For Moore and Joyce, the practices of managerialism have been intensified by the rise of platform capitalism. With the development of new information technologies, managers have been able to dissect and rearticulate in more precise and intense ways the practices of scientific managerialism and the control over labour. The model of platform work managerialism encompasses, among significant features, an algorithmic allocation of work and the use of digital tracking technologies to enforce and control the labour process. It highlights how new technologies enable practices of scientific management to be refreshed and reconfigured for the current era of capitalism.

Baglioni, Campling and Hanlon are keen to characterize managerialism as an entrepreneurial function that relates to corporate governance and which should be distinguished from public governance. For this reason, they insist on the importance of distinguishing managerialism from neoliberalism. While the latter represents a structure of governance that is based on intensifying processes of commodification and the intensification of competition, the former signals a means by which competition can be delivered within value chains. Distinguishing 
between them helps us better grasp the nature of managerialism as a tool of control, but also the reason why, in the current context, these practices have fared so well. What was initially concerned with organising the division of labour has thus been fleshed out into a broader practice of standardisation which helps managers to exert further control over value capture. It has fuelled a process of 'concentration and control' of knowledge production to the benefit of elite actors within the socio-economic class hierarchy.

A second key concept which is related to the notion of capitalism but more historically specific is the emphasis on neoliberalism. Although early phases in the development of managerialism through the twentieth century are each important on their own, many recent studies have focused on developments since the 1980s and 1990s. Scholars have emphasised the turn to quality management, benchmarking, the audit culture, performance management, among others agendas and tools, as being part of a neoliberal project (Power 1999; Bruno and Didier 2013). The focus here often revolves around the strong impact of managerialism on the public sector and the rise of public management which is often interpreted as a means to promote a new forms of corporate empowerment (Fouger 2008; Davies 2014).

In their article, Sharma and Soederberg point to the way in which global risk management has promoted new practices of valuation that have been pivotal to justifying the greater involvement of transnational corporations in projects of development. These have underpinned what they see as a new Davos consensus, aimed at consolidating and legitimising 'the role of business as an active development agent, whilst depoliticizing the social and environmental disruptions tied to this arrangement'. Focusing on a different point, Whiteside shows, in discussing the rise of public private partnerships, how managerialism has played a key role in normalising the involvement of the private sector by recasting public sectors from service providers into commodity purchasers.

Examining the growing influence of management consultancies in the making of the global development agenda, Seabrooke and Sending's article explores how the new forms of managerialism have been tied to professional practices. As they show, managerialism has promoted a distinctive cultural frame which values abstract templates, as well as a kind of short-termism, such as seen in the 'work to contract' trends in International Governmental Organisations (IGOs) they document. These are often crafted to elicit further work by avoiding controversial suggestions and generating growing dependency towards consultants.

Others contributors are keen to understand managerialism as a discrete set of ideas, cultural frames and technologies that, although operating in a capitalist environment, have a certain autonomy and should be analysed on their own terms. This initial differentiation is then often used as a means to highlight the counterintuitive nature of managerial practices, which are too often normalised in the IPE literature (Knafo et al. 2018). The objective of these discussions is, therefore, to problematize the role of specific institutions often neglected in IPE, such as business schools (Linsi, Hanlon, Knafo) or management consultants (Seabrooke and Ole Jacob; Whiteside; Eagleton-Pierce).

Instead of taking the scientific management of the early $20^{\text {th }}$ century as its benchmark for thinking about managerialism, scholars who adopt this focus often turn to the rise of management science in the postwar era, a period which featured the profound renovation of 
business schools and the dramatic development of new optimisation techniques. From this time, we see a more abstract and generalist form of action which focused on strategic questions, rather than the more applied concerns of scientific management. It is a development often associated with the growth of business schools and management consultancy firms. Such trends reflected a growing interest in quantification and mathematical modelling and marked, more broadly, an increasing self-awareness of management as a general expertise considered independent of any specific field of operations. It has been the target of a rich literature criticising 'management by numbers' which was often seen to be responsible for increasing the gap between top management and other workers within firms or organisations (O'Sullivan 2001).

Within the parameters of this perspective, Linsi's article highlights that the neoliberal era has been shaped by ideas that cannot be easily slotted into the classic paradigms of IPE, such as Keynesianism and neoliberalism. The political commitment to chasing foreign investors is a case in point which, Linsi argues, highlights the specific role of business studies and managerial ideas in shaping the agenda of neoliberalism in ways that are not easily captured by the focus on neoliberal theory or, more generally, the impact of economics on policy. As he suggest, such thinkng enabled a profound shift away from the traditional emphasis on national champions towards attracting foreign investors, a priority that went against the conventionl emphasis on national industries which had long been characteristic of economics.

For Knafo, this new manargeialism should not be directly read as the product of the growing influence of corporations, but rather as the outcome of long lineages that finds their roots in the key innovations made by the US defense sector and practices that were borne out of the experience of the Second World War. This helps to highlight that current managerial ideas and practices depart much more fundamentally from what we would take to be a 'corporate' or 'capitalist' mindset. Having been driven by scientists who often had little prior knowledge of military affairs, it framed a distinct dynamic whereby decision makers were empowered over specialists or professionals in military matters, just as it would later be the case in the public sector with the destitution of professionals in favour of a new managerial class.

Finally, Eagleton-Pierce argues that managerialism can be situated in relation to long-standing organisational concerns around instrumental rationality and the desire for control. In respect to his particular focus on the origins of performance management or results-based management, he suggests that the legacy of this thinking can be found in both corporate and public sector environments from the 1960s and 1970s, in the process problematising a presumed neat fit between managerialism and neoliberalism. When applied to the case of international NGOs in global development, Eagleton-Pierce suggests that performance managerial agendas became more prominent from the 1990s onwards. He suggests that governments, international organisations, and private consultants were all important players who helped to normalise managerialism within major transnational NGOs.

\section{The Political Consequences of Managerialism}

This special issue aims to highlight why and how managerialism deserves to be interrogated by IPE theorists as a multifaceted object of analysis with important political consequences. 
We aim for the issue to constitute a stepping stone for a broader reflection on the ways in which managerialism dovetails or clashes with other major systems of ideas in the global economy; on how it is appropriated and mobilized by different social forces and agents for different ends; on the complex processes of translation as these ideas circulate from one social field to the next; as well as the diversity in managerial practices across countries, sectors, and institutional spaces. For it is our belief that many of the key political struggles of our time are increasingly mediated by managerial institutions and discourses that help shape what is politically at stake in the global political economy. The contributions to this special issue all build on the idea that coming to terms with managerialism is a vital aspect of politics in the neoliberal era. It is increasingly setting the parameters for what is considered to be a legitimate political intervention and has helped diffuse corporate ways of doing things which, in turn, often close off accountability measures or narrow the policy agenda.

Seabrooke and Sending, for example, point to the way in which consultancy houses have fuelled a general trend towards managerialism in IGOs with distinct professional and organizational features. The generalization of this abstract managerialism has played an important role in a narrowing of the policy or development space, both in terms of the ideas that are considered and the processes through which these organizations operate.

Whiteside highlights the ways in which managerialism has helped leverage the public sector activities on financial markets in ways which conceal the investments of the public sector and the costs of relying on private contractors. She captures how managerialism has thus become a key vehicle for the involvement of private firms and organisation in the public sector and more generally in the process of policy making.

In Nunn's research on ALMPs he argues that performance management agendas tend to lead to centralised control dynamics within bureaucracies that have a stake in such policy games. He suggests that the relative distributional form of the welfare state is being reshaped through justifications derived from a managerial sensibility. In this sense, by analysing how consultants and public sector managers vie for the authority to shape the performance management of labour markets, Nunn argues that managerialism is implicated in 'significant social harm' for those precarious workers caught up finding work in the such systems.

In the process of mediating social struggles over the global economy, managerialism has transformed the nature of political struggles and how agents conceive of what is at stake in political struggles over the future of the global economy. In this regard, the study of managerialism is particularly relevant in the field of development, as Sharma and Soederberg highlight, because this field is too often neglected by work on managerialism. As they point out, the global risk management agendas in the World Economic Forum (WEF) has empowered major corporations to legitimately participate in international development problems. Their article documents how the rise of risk management - with its appearance of progress, order, and predictability - offers a vehicle for major firms to downplay their own historical role in negative socio-economic trends and outcomes. In short, they argue that the WEF discourse on risk management tends to reproduce a harmonious and ahistorical view of the subject matter, without adequate attention to how business seeks to replenish its particular legitimacy within hierarchical systems of power. 
For Knafo, the rise of managerial governance should be understood as a means to facilitate decision making at the top of organizations, for example in the making of policy, rather than in reference to those at the bottom, as was the case with the Taylorist focus on restructuring the labor process. This paradigmatic shift has fuelled the rise of a managerial class. In that regards, it is important to realise that we may be fighting the wrong battle in assuming that governance is currently focused on extending and intensifying market rule in all aspects of society (c.f. Peck 2010). As our gaze continues to be transfixed on the market pressures that are too said to be driving change, we lose sight of the rise of a managerial class that is profoundly transforming the nature of governance and capitalist accumulation. We too often take-for-granted the script according to which managers have no real alternative to the managerial policies they implement because of growing market pressures. Turning the spotlight back on decision makers is therefore key.

In Eagleton-Pierce's study of NGOs in the field of international development, he charts how managerialism rose from being a marginal phenomenon in the 1980s to something that was increasingly viewed as 'fundamental', or even 'existential', from the early 2000s. Through the particular case of Oxfam, he argues that the rationale for performance management is manifested and concretely operationalized through an agenda on monitoring, evaluation, and learning (MEL). Eagleton-Pierce explains how and why the spreading of this form of managerialism unfolded via attention to both structural tendencies, such as funding policies in donor governments and IOs, as well as internal debates within Oxfam. He documents not only the ways in which this normalisation process evolved, but also the critique and resistance it provoked from NGO workers and analysts. Eagleton-Pierce argues that the turn to managerialism in the case of Oxfam 'reflects a more pervasive anxiety about institutional comportment and how to appear to others as a "modern" organisation'. 


\section{REFERENCES}

Alvesson, M. and and Willmott, H. (2012). Making Sense of Management: A Critical Introduction. London: Sage.

Amoore, L. (2002). Globalisation Contested: An International Political Economy of Work, Manchester: Manchester University Press.

Amoore, L. (2006). Making the Modern Multinational. in May, C. (ed.). Global Corporate Power. Boulder, CO: Lynne Rienner.

Baines, J. (2017). Accumulating Through Food Crisis? Farmers, Commodity Traders and the Distributional Politics of Financialization. Review of International Political Economy, 24 (3). 497-537.

Bauman, Z. (1991). Modernity and Ambivalence. Cambridge: Polity.

Beniger, J. (1989). The Control Revolution: Technological and Economic Origins of the Information Society. Cambridge, MA: Harvard University Press.

Berry, A. J., Coat, A. F., Harris, E. P., Otley, D. T., and Stringer, C. (2009). Emerging Themes in Management Control: A Review of Recent Literature. The British Accounting Review, $41(1), 2-20$.

Best, J. (2014). Governing Failure: Professional Expertise and the Transformation of Global Development Finance. Cambridge: Cambridge University Press.

Braverman, H. (1974). Labor and Monopoly Capital. New York: Monthly Review.

Broome, A. and Quirk, J. (2015). Governing the World at a Distance: The Practice of Global Benchmarking. Review of International Studies, 41 (5), 819-841.

Bruno, I. and E. Didier (2013). Benchmarking: L'État sous pression statistique. Paris, Zones.

Budd, A. (2013). Class, States and International Relations: A Critical Appraisal of Robert Cox and Neo-Gramscian Theory. Abingdon: Routledge.

Burnham, J. (1941). The Managerial Revolution: What is Happening in the World. New York: John Day.

Büthe, T. (2010). Global Private Politics: A Research Agenda. Business and Politics, 12 (3), 124.

Büthe, T. and Mattli, W. (2011). The New Global Rulers: The Privatization of Regulation in the World Economy. Princeton: Princeton University Press.

Chau, W. F., Lowe, T., Puxty, T. (eds) (1989) Critical Perspectives in Management Control. Houndsmills: Macmillan.

Clegg, S. (1981). Organization and Control. Administrative Science Quarterly, 26 (4), 545-562.

Cox, R. W. (1987). Production, Power, and World Order: Social Forces in the Making of World History. Columbia: Columbia University Press.

Cox, R. W. (1993). Structural Issues of Global Governance: Implications for Europe. in Gill, S. (ed.). Gramsci, Historical Materialism and International Relations. Cambridge: Cambridge University Press.

Cunliffe, A. L. (2014). A Very Short, Fairly Interesting and Reasonably Cheap Book About Management. London: Sage.

Dannreuther, C. and Lekhi, R. (2000). Globalization and the Political Economy of Risk', Review of International Political Economy, 7 (4), 574-594.

Davies, W. (2014). The Limits of Neoliberalism: Authority, Sovereignty and the Logic of Competition. London: Sage.

Drucker, P. (1973). Management: Tasks, Responsibilities, Practices. New York: Harper \& Row. 
Edwards, R. (1980). Contested Terrain: The Transformation of the Workplace in the Twentieth Century. New York: Basic.

Ferguson, J. (1994). The Anti-Politics Machine: Development, Depoliticization and Bureaucratic Power in Lesotho. Minneapolis, MN: University of Minnesota Press.

Fuchs, D. (2007). Business Power in Global Governance. Boulder, CO: Lynne Rienner.

Giddens, A. (1991). Modernity and Self-Identity: Self and Society in the Late Modern Age. Stanford: Stanford University Press.

Gill, S. (1995). Globalisation, Market Civilisation, and Disciplinary Neoliberalism. Millennium: Journal of International Studies, 24 (3), 399-423.

Graeber, D. (2015). The Utopia of Rules: On Technology, Stupidity and the Secret Joys of Bureaucracy. Brooklyn, NY: Melville House.

Grey, C. (1996). Towards a Critique of Managerialism: The Contribution of Simone Weil. Journal of Management Studies, 33 (5), 591-611.

Grey, C. (2017). A Very Short, Fairly Interesting and Reasonably Cheap Book About Studying Organizations. London: Sage.

Hall, R. B. and Biersteker, T. J. (eds) (2002). The Emergence of Private Authority in Global Governance. Cambridge: Cambridge University Press.

Harrison, G. (2005). The World Bank, Governance and Theories of Political Action in Africa. British Journal of Politics and International Relations, 7, 240-260.

Hood, C. (2002). The Risk Game and the Blame Game. Government and Opposition, 37 (1), 1537.

Hood, C. (2010). The Blame Game: Spin, Bureaucracy, and Self-Preservation in Government. Princeton: Princeton University Press.

Hoskin, K. and Macve R. (1994). Reappraising the Genesis of Managerialism: A Reexamination of the Role of Accounting at the Springfield Armory, $1815-1845$. Accounting, Auditing \& Accountability Journal, 7 (2), 4-29.

Hymer, S. (1970). The Efficiency (Contradictions) of Multinational Corporations. The American Economic Review, 60 (2), 441-448.

Fougner, T. (2006). The State, International Competitiveness and Neoliberal Globalisation: Is There a Future Beyond "the Competition State"?'. Review of International Studies, 32 (1), 165-185.

Fouger, T. (2008). Neoliberal Governance of States: The Role of Competitiveness Indexing and Country Benchmarking. Millennium: Journal of International Studies, 37 (2), 303-326.

Kallinikos, J. (1996). Mapping the Intellectual Terrain of Management Education. in French, R. and Grey, C. (eds). Rethinking Management Education. London: Sage.

Knafo, S. and S. J. Dutta (2016). Patient Capital and the Financialisation of Management. SocioEconomic Review, 14 (4), 771-788.

Locke, R. R. and Spender, J-C. (2012). Confronting Managerialism: How the Business Elite and their Schools Threw Our Lives Out of Balance. London: Zed Books.

Lockwood, E. (2015). Predicting the Unpredictable: Value-at-risk, Performativity, and the Politics of Financial Uncertainty. Review of International Political Economy, 22 (4), 719756.

Luke, T. W. (1990). Social Theory and Modernity: Critique, Dissent, and Revolution. London: Sage.

MacIntyre, A. (2014[1981]). After Virtue. London: Bloomsbury Academic.

May, C. (ed.) (2006). Global Corporate Power. Boulder, CO: Lynne Rienner. 
May, C. (2015). Who's in Charge? Corporations as Institutions of Global Governance. Palgrave Communications. 15042. http://dx.doi.org/10.1057/palcomms.2015.42.

Momani, B. (2013). Management Consultants and the United States' Public Sector. Business and Politics, 15 (3), 381-399.

Niskanen, W. (1971) Bureaucracy \& Representative Government, London: Aldine.

O'Sullivan, M. (2001). Contests for Corporate Control: Corporate Governance and Economic Performance in the United States and Germany. Oxford: Oxford University Press.

Otley, D., Broadbent, J., and Berry, A. (1995) 'Research in Management Control: An Overview of its Development'. British Journal of Management, 6 (s1), S31-S44.

Ougaard, M. and Leander, A. (eds) (2010). Business and Global Governance. Abingdon: Routledge.

Parker, M. (2002). Against Management, Cambridge: Polity Press.

Peters, J. (2012). 'Neoliberal Convergence in North America and Western Europe: Fiscal Austerity, Privatization, and Public Sector Reform'. Review of International Political Economy, 19 (2). 208-235.

Perry, J. and Nölke, A. (2006). The Political Economy of International Accounting Standards. Review of International Political Economy, 13 (4), 559-586.

Pollitt, C. (1993). Managerialism and the Public Services: The Anglo-American Experience. Oxford: Blackwell.

Power, M. (2004). Counting, Control and Calculation: Reflections on Measuring and Management. Human Relations, 57 (6), 765-783.

Power, M. (2007). Organized Uncertainty: Designing a World of Risk Management. Oxford: Oxford University Press.

Reed, M. I. (1989). The Sociology of Management. Hemel Hempstead: Harvester Wheatsheaf.

Roberts, J. (1984). The Moral Character of Management Practice. Journal of Management Studies, 21 (3), 287-302.

Schwartz, H. (1994). Small States in Big Trouble: State Reorganization in Australia, Denmark, New Zealand, and Sweden in the 1980s. World Politics, 46(4), 527-555.

Seabrooke, L. and Henriksen, L. F. (eds) (2017). Professional Networks in Transnational Governance. Cambridge: Cambridge University Press.

Sklair, L. (2001). The Transnational Capitalist Class. Oxford: Wiley-Blackwell Publishing.

Stopford, J. and Strange, S, with Henley, J. S. (1991). Rival States, Rival Firms: Competition for World Market Shares. Cambridge: Cambridge University Press.

Strange, S. (1988) States and Markets: An Introduction to International Political Economy. London: Pinter.

Strange, S. (1996). The Retreat of the State: The Diffusion of Power in the World Economy. Cambridge: Cambridge University Press.

Townley, B. (2002). Managing with Modernity. Organization, 9 (4), 549-573.

Thrift, N.J. (1997a). The Rise of Soft Capitalism. Cultural Values, 1 (1), 29-57.

van der Pijl, K. (1993). Transnational Classes and International Relations. Cambridge: Cambridge University Press.

van der Pijl, K. (2005). Gramsci and Left Managerialism. Critical Review of International Social and Political Philosophy, 8 (4), 499-511.

van der Pijl, K. (2012). The Making of an Atlantic Ruling Class. London: Verso.

Vernon, R. (1971). Sovereignty at Bay: The Multinational Spread of U.S. Enterprises. London: Longman. 
Vernon, R. (1977). Storm Over the Multinationals: The Real Issues. Cambridge, MA: Harvard University Press.

Watson, T. (1994). In Search of Management. London: Routledge.

Weaver, R. K. (1986). The Politics of Blame Avoidance. Journal of Public Policy, 6 (4), 371-398.

Weber, M. (2013[1922]). Economy and Society. Berkeley: University of California Press. 